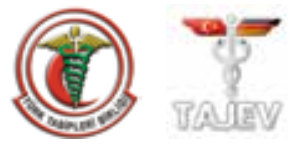

\title{
Ovarian aging and premature ovarian failure
}

\author{
Yavuz Emre Şükür' İçten Balık KIvançlı², Batuhan Özmen ${ }^{3}$ \\ 'Department of Obstetrics and Gynecology, Kayseri Training and Research Hospital, Kayseri, Turkey \\ ${ }^{2}$ Department of Obstetrics and Gynecology, Gazimagusa State Hospital, Gazimagusa, Turkish Republic of Northern Cyprus \\ ${ }^{3}$ Department of Obstetrics and Gynecology, Ankara University Faculty of Medicine, Ankara, Turkey
}

\section{Abstract}

Physiological reproductive aging occurs as a result of a decrease in the number and quality of oocytes in ovarian cortex follicles. Although the reason for the decrease in the quality of the pool and follicular oocytes is not fully understood, endocrine, paracrine, genetic, and metabolic factors are thought to be effective. Nowadays, in order to understand the mechanisms of ovarian aging, genomic research has gained importance. The effect of co-factors, such as telomerase and ceramide, in the ovarian aging process is only getting ascertained with new research studies. The most important tests in the assessment of ovarian aging are antral follicle count and anti-Mullerian hormone.

(J Turk Ger Gynecol Assoc 2014; 15: 190-6)

Key words: Ovarian aging, premature ovarian failure, reproduction

Received: 28 January, $2014 \quad$ Accepted: 26 March, 2014

Available Online Date: 08 August, 2014

\section{Introduction}

The fertility capacity of women diminishes in parallel with aging. As the level of education of women has increased since the 1960 s and they have become more active in working life and have had easier access to contraceptive methods, the need to have children has been postponed to advanced ages by more women $(1,2)$. As a result of the postponing of maternal age, the number of patients that are not able to get pregnant within 12 months and apply to artificial reproductive technologies (ART) with a female infertility diagnosis has been increased. Among women, the normal process of reproductive aging has great variations; some women continue to be highly fertile in their $40 \mathrm{~s}$, while others lose their fertility in their 30s. The process of reproductive aging in women mostly stems from the changes in ovarian function due to chronological aging. Ovaries are affected by natural aging more than all other tissues. Although the reason is not fully understood, endocrine, paracrine, genetic, and metabolic factors are thought to be affecting the decrease in the quality of the follicular pool and oocytes.

Ovarian aging resulting in ovarian failure and menopause is an on-going process. Of the early signs of ovarian aging, failure to adequately respond to ovarian stimulation, followed by menstrual irregularity and the loss of follicle functions, can be listed. In accordance with the 'fixed interval hypothesis,' the period between the first menstrual cycle irregularities and menopause is constant-approximately 6 years-and is independent from the age of menopause $(3,4)$. It is believed that the process of physiological reproductive aging stems from the decrease in the number and quality of the oocytes in the ovarian cortex follicles. This reduction process in the oocytes accelerates with aging and increases especially after the age of 38 with a biphasic pattern (5). The monthly fecundity decreases approximately from the age of $30(6,7)$. The first but inconspicuous sign of reproductive aging process is 2-3 days of shortening of the menstrual cycle (8). Menopausal transition is defined as the stage of ovarian aging and starts approximately at the age of 46 (8). The last menstrual period (menopause) is expected approximately at the age of 51 (range 40-60) and is considered as the physiological sequel of ovarian aging $(9,10)$. In the last century, in spite of the increase in life expectancy and decrease in menarche age, there has been no significant change in menopausal age. It is thought that genetic control is important and that environmental factors are effective in determining the natural menopausal age (11).

\section{Endocrinological Factors in Ovarian Aging}

During reproductive life, the length of a regular menstrual cycle is typically 28 days. The increase in the early follicular FSH level before the onset of menstrual irregularity during the menopausal transition period may point out a decrease in the number follicles. During the menopausal transition period, the menstrual cycles worsen further due to the decrease in the FSH-sensitive follicles. As a result of the selection of dominant follicles, the follicular phase shortens (12). Then, the delay in the development of dominant follicles or withdrawal of estrogen without corpus luteum function causes extended cycles and anovulatory hemorrhages (13). 
As a result of the declining cohort of antral follicles, first inhibin B secretion decreases, then estradiol, and finally inhibin A secretion. This then results in changes in the feedback mechanism. In the menopausal transition stage, a clear decrease in inhibin B levels can be noted along with further increases in FSH levels, and this indicates a decreased number of antral follicles (14). Estradiol and inhibin A levels remain largely unaltered until the later stages of the menopausal transition. Only when periods of amenorrhea become lengthy will levels of these hormones decrease and contribute to the loss of negative ovarian feedback in the late stages of ovarian aging (15). Luteal phase endocrinology does not significantly change with advancing age. In case ovulation still occurs, the secretion of estradiol, progesterone, and inhibin A from the corpus luteum seems unaltered (16). In late-reproductive-period women who still have regular menstrual cycles, elevations of FSH affect ovarian function. The elevated early follicular FSH levels will often drive more than one single follicle into dominance, resulting in elevated early follicular estradiol levels and the increased occurrence of dizygotic twinning (17).

During early fetal development, human oocytes initiate meiosis. Oocytes subsequently enter prophase, and genetic material is exchanged between homologous chromosomes (recombination). Following that, oocytes progress to the diplotene phase, but this process pauses at meiosis 1 (MI) (18). At this stage, oocytes are surrounded by a single layer of granulosa cells, forming the primordial follicle. Primordial follicles generally remain quiescent for years. The initial follicular maturation from the resting primordial follicle to the Graafian preovulatory follicle takes several months. The majority of follicles enters atresia at some stage during this maturation process (19). The follicular meiotic division is only completed with ovulation, which is induced by the mid-cycle LH increase. One group of chromosomes remains in the oocyte, whereas the other is segregated in the first polar body. By the completion of this first division, the number of chromosomes is reduced to half. Only in the case of fertilization is the second division completed (MII). Hence, all steps are under the influence of certain signals, and the entire process may last many decades. It is suggested that oocytederived factors, such as growth differentiation factor 9 (GDF9) or bone morphogenetic protein 15 (BMP15) may be effective in regulating folliculogenesis $(20,21)$.

\section{Genetic Factors in Ovarian Aging}

The association between menopausal age of mothers and daughters and also between sisters has suggested that the genetic factors are effective on the reproductive aging process. The heritability for age at menopause is estimated to range from $30 \%$ to $85 \%$ (22). Premature ovarian failure (POF) cases without an obvious cause may be considered to be part of the variation of menopause, and therefore, POF may offer a unique model for the study of the genetic mechanisms of ovarian aging. Genes, like FSH, FSHR, LH, LHR, CYP17, and CYP19, that exert known hormonal effects primarily affect follicle function, whereas genes like BMP15, GDF9, and GPR3 affect the rate of initial selection from the primordial follicle pool. Mutations and small variations in these genes could result in the decrease of the life of the follicle pool and the reproductive life span $(23,24)$. Genes expressed during oogenesis may lead to various degrees of germ cell formation. These genes include DNA-binding proteins and transcription factors, like NOBOX (newborn ovary homeobox) and LHX8, and RNA-binding proteins, like NANOS. NOBOX, GDF9, and LDX8 mutations directly causing POF have indeed been identified in few women (25). Recently, the first genome-wide association analysis has revealed that POF is linked to the ADAMts9 gene (26). Two chromosomal regions have been determined with a genome-wide scan carried out on sibling sisters: 9q21.3 and Xp21.3 (27). In more than $28 \%$ of femail fragile $X$ permutation carriers, POF occurs, and a gene at chromosome 9 linkage region encodes for a member of the BCL2 family, which is involved in apoptosis $(28,29)$. In genome-wide studies on menopausal women, it has been determined that several single-gene polymorphisms on chromosomes 5, 6, 13, 19, and 20 are associated with menopausal age (30, 31). Micro-deletions involving GDF9, BMP15, and FOXL2 have been shown to produce early ovarian arrest (3234). Also, the estrogen-inactivating polymorphism CYP1B1-4 appears to have relations with early menopausal age (35). With this polymorphism, higher levels of estrogens throughout the reproductive life are believed to exist, but the way in which this would affect the ovarian follicular pool remains to be elucidated. Common polymorphisms in the gene for AMH receptor 2 have been associated with age at menopause in two large cohorts. Less active AMH signaling would lead to weaker inhibition of initial follicle recruitment, resulting in a possible increased rate of follicle loss (36).

Mitochondrial energy production has a key role in cell proliferation and apoptosis. The mitochondria's own genetic material (mtDNA) is inherited maternally. Increase in mtDNA deletions in luteinizing granulosa cells after the age of 38 shows a reduction in the levels of antioxidant enzymes and consequently accelerates apoptosis in oocytes with the increase of certain factors, such as ceramide $(37,38) . \mathrm{Ca}^{2+}$ fluctuations in abnormal mitochondria will not stimulate the production of ATP, which supports the normal physiological process, and fertility is affected.

\section{Micro-environmental Factors in Ovarian Aging}

Telomeres are DNA nucleotide sequences and specific proteins located at the ends of all eukaryotic chromosomes. Telomeres in human beings consist of repetitive several thousand consecutive pieces of TTAGGG double-stranded sequence. Telomeric DNA normally terminates with a single strand at the 3' end. This particular configuration blocks end-to-end binding of the chromosomes and provides protection. However, in each chromosome replication, depending on the end replication problems, 100-200 base pairs (bp) of telomeric DNA is lost, and gradually, telomeres become shorter (39). Telomeres in humans regress from 10-15 kilobases (kb) to 2-5 kb during a life span. For this reason, telomeres are also known as a mitotic clock, and the remaining telomeres show the proliferative capacity of a cell. The telomere end replication problem is solved by the telomerase enzyme complex. Telomerase is an RNA enzyme connected to telomeres and provides protection and positively 
contributes to its length (40). With aging, telomerase activity is reduced in human ovarian cells (41). Telomerase activity was detected especially in early antral and preovulatory follicles, as well as ovulated oocytes, but a significant decrease is observed with maturation $(42,43)$. Although there is no correlation between telomerase and FSH levels, telomerase activity may be a good indicator for the functional age of the ovary.

Reactive oxygen and nitrogen species produced during biological metabolism are referred to as free radicals. According to the generally accepted theory, intramitochondrial electron leakage occurs as a result of age-related decrease in cellular respiration, and this impairs mtDNA stability and mitochondrial function (44). Oxidative stress occurs when the production of free radicals exceeds the cleaning capability of antioxidants. This imbalance creates oxidative damage and ultimately leads to the release of cytochrome $\mathrm{c}$ and other apoptosis-stimulating factors. Thus, cell death occurs $(45,46)$. Oxidative stress due to aging in a sense is caused by the weakening of the antioxidant enzymatic defense. Glutathione (GSH) and glutathione transferase (GST), which are effective in the removal of free radicals, are reduced in oocytes with age (47). With the weakening of the antioxidant defense, aging occurs in granulosa cells, accompanied by $\mathrm{Cu} / \mathrm{Zn}$ superoxide dismutase, Mn superoxide dismutase, and catalase down-regulation (48). As a result, the increase in oxidative damage associated with the weakening of antioxidant defense mechanisms causes aging of the ovaries.

Ceramide, which is a precursor of the sphingolipid secondary messenger, is responsible for cellular silence and physical aging (49). In female germ cells, an increase in apoptosis is observed with aging, and this requires communication between the oocyte and the surrounding cumulus cells. In animal experiments, it is indicated that with aging, ceramides exit the cumulus cells and pass to the neighboring oocyte and initiate apoptosis, and it is also shown that this incident may be prevented by sphingosine-1-phosphate (38). This exchange of ceramide is only possible if there is a gap-junction and a complete lipid transport system between the cumulus cells and the oocyte. In addition, in oocyte susceptibility to ceramide increases with aging (38).

Formation of advanced glycation end-products (AGEs) is an irreversible process that increases with cases, such as aging, atherosclerosis, and diabetes mellitus. AGEs cause tissue damage by protein cross-linkage or by connecting special receptors, called RAGE (receptor for advanced glycation end-products) (50). AGE-RAGE connection causes cellular oxidative stress. Ovarian dysfunction due to AGEs might relate to ART outcomes and measures of ovarian reserve (51).

The level of oxygen provided by perifollicular vascularization and paracrine regulators is necessary for a healthy micro-environment. The fertilization and development potential of oocytes with complete vascularization and high levels of oxygen $(\geq 3 \%)$ are higher $(52,53)$. Increased perifollicular vascularization in IVF patients increases the rate of live births (54).

\section{Assessment of Ovarian Aging}

Nowadays, methods of ultrasonographic assessment of ovarian aging include antral follicle count, ovarian volume, and ovar- ian blood flow measurement. During ART, in order to assess the ovarian response, antral follicle count is more sensitive to ovarian volume measurements (55). However, both ultrasound tests have low predictive values for pregnancy. Clinically, the most widely used test is antral follicle count, as this test is easy, cheap, and reliable. The decreasing stromal blood flow of women with low ovarian reserve is monitored by Doppler ultrasonography. Doppler ultrasound measurement of blood flow can be used as a marker of premature ovarian aging in the future.

Traditional tests that are used to assess the ovarian reserve of patients undergoing ART include the basal follicle-stimulating hormone (FSH) in early follicular phase, estradiol, inhibin B, and $\mathrm{FSH} /$ luteinizing hormone (LH) ratio. High FSH level is an irrefutable marker for ovarian aging; however, it increases 10 years prior to menopause or when infertility occurs. Therefore, it is not a very useful test. In addition, estradiol and inhibin A levels in the early follicular phase are stable until late menopausal transition period and therefore must not be used as a test of ovarian aging. In addition, these tests have low predictive values for pregnancy and ovarian response. Anti-Müllerian hormone (AMH) and inhibin B are members of the TGF-B (transforming growth factor-B) family. $\mathrm{AMH}$ is an important ovarian aging test for the evaluation of follicular pool. It is expressed as early as the $36^{\text {th }}$ gestational week, and serum levels are gradually increased in the first 3-4 years and become stable until puberty (56). AMH, which is a dimeric glycoprotein, is secreted to the serum from the granulosa cells of early developing follicles, especially from pre-antral and small antral follicles. It has a strong correlation with the antral follicle count (57). Early stages of follicular development are mainly inhibited by AMH. One of the major advantages of the $\mathrm{AMH}$ test is that the serum levels remain constant throughout the entire menstrual cycle (58). AMH becomes undetectable approximately 5 years before menopause occurs (59). It has high predictive value for poor ovarian response in clinical practice, for cycle cancellation, excessive ovarian response, and ovarian hyperstimulation syndrome (60). However, the importance is not yet certain for embryo quality, implantation, and pregnancy rates. Inhibin B is mainly secreted from FSH-sensitive antral follicles. The shrinkage of this cohort with advancing age will cause inhibin B levels to decrease. The dynamic tests for ovarian aging include clomiphene citrate challenge test (CCCT) and $\mathrm{GnRH}$ agonist stimulation test. However, the dynamic tests are not frequently used, as they take a longer time and are expensive and complicated. In addition, there is no superiority of these tests from the described static tests (61).

Genome-wide studies have been conducted to investigate ovarian aging-related genes, including particular candidate genes. But, as yet, there is no test that can be used in routine practice. Another strategy is to investigate the genetic disorders known to POF. This group covers $20 \%-25 \%$ of the patients previously classified as idiopathic (62). The most common genetic disorders include $\mathrm{X}$ chromosome abnormalities, FMR1 premutation, and the more recently identified BMP15, FIGLA, GDF9, and NR5A1 gene mutations (62). 


\section{Premature Ovarian Failure}

In women, primary hypogonadism is defined as ovarian insufficiency accompanied by high serum levels of FSH. POF, which is also referred to as primary ovarian insufficiency, is primary hypogonadism before the age of 40 . POF is characterized by loss of follicles, folliculogenesis, estrogen production, and infertility. It is not essential to observe amenorrhea for the diagnosis of POF, as spontaneous menstrual cycles can be seen after the diagnosis as well. The disorder affects approximately $1 \%$ of women below the age of 40 and $0.1 \%$ before the age of 30 (63). The incidence is $10 \%-28 \%$ in women with primary amenorrhea and 4\%-18\% in women with secondary amenorrhea (64). Most of these patients undergo a normal pubertal process and regular menstrual cycles. Irregularity in the menstrual cycle is the most common symptom. In women diagnosed with POF, estrogen production and ovulation can be seen. Normal pregnancy may occur in 5\%-10\% of these patients (65).

\section{Etiology}

Approximately $20 \%-30 \%$ of the relatives of POF patients are also affected (66). The genetic causes of POF include X chromosome abnormalities and single gene disorders. Defects of the $\mathrm{X}$ chromosome include partial deletion, translocations, and missing or extra chromosomes. Turner syndrome is mosaic or complete monosomy of the X chromosome. Both $\mathrm{X}$ chromosomes are required for the completion of oogenesis; therefore, ovarian function is defective in Turner syndrome. Although it is difficult to assess the exact locus, it is thought that it may be due to a defect in the Xp11.2-p22.1 region (67). Trisomy X syndrome $(47, \mathrm{XXX})$ is caused by the attachment disorder of the $\mathrm{X}$ chromosome during maternal meiosis, and this may cause POF, too (68). Mental retardation, growth retardation, tremor, ataxia, and dementia are observed in fragile $\mathrm{X}$ syndrome premutation carriers; $16 \%-21 \%$ of these patients are at risk of POF (69). It has recently been thought that $6 \%$ of POF patients are fragile $X$ carriers (70). CGG triplet repeats of the first exon of the X-linked FMR1 (familial mental retardation-1) gene cause fragile $\mathrm{X}$ syndrome. Premutation is defined as between 50 to 200 repeats. POF risk is higher when the premutation is transferred from the father (28\%) than the mother (4\%) (71). While the frequency of the FMR1 premutation is $14 \%$ for familial POF patients, this rate is $2 \%$ for sporadic cases (69, 72). Single-gene disorders include FSH and $\mathrm{LH}$ receptor mutations, inhibin mutations, and galactosemia. A particular $\mathrm{FSH}$ receptor mutation $(566 \mathrm{C}>\mathrm{T})$ causes ovarian failure and amenorrhea in some Finnish families (73). Mutations in the inhibin $\alpha$ and $\beta$ genes cause severe symptoms of POF. Amenorrhea at the age of 10 occurs in $7 \%$ of patients (74). An INHA G769A special mutation is detected in approximately $5 \%$ of patients with POF (75). Galactosemia is an autosomal recessive disease, and $80 \%$ of patients develop POF (76). As a result of a galactose-1-phosphate uridyl transferase gene mutation, the accumulated toxic level of galactose metabolites in the ovaries develops POF. There are many other autosomal gene loci identified in patients with POF. Mutation of the FOXL2 transcription factor gene, which is located on chromosome 3 , is one of the causes of POF (77). Also, BMP15, GDF9,
Table 1. Gonadotoxic risks of chemotherapeutic agents

\begin{tabular}{|l|l|l|}
\hline High risk & Medium risk & Low risk or no risk \\
\hline Cyclophosphamide & Cisplatin & Methotrexate \\
\hline Busulfan & Adriamycin & 5-Fluorouracil \\
\hline Melphalan & $\begin{array}{l}\text { Paclitaxel } \\
\text { (needs } \\
\text { more } \\
\text { studies) }\end{array}$ & Actinomycin D \\
\cline { 1 - 1 } Procarbazine & Bleomycin \\
\cline { 1 - 1 } Nitrogen mustard & Vincristine \\
\hline
\end{tabular}

phosphomannomutase 2 (PMM2), FRAXA, and POF1B gene mutations are causes of POF (78-80).

Three enzymatic defects in the steroidogenic pathway cause hypergonadotropic amenorrhea. These are $17 \alpha$-hydroxylase (17,20-lyase), 20,22-lyase, and aromatase deficiencies. $17 \alpha$-hydroxylase deficiency can be easily detected, as it develops primary amenorrhea, absence of secondary sexual characteristics, hypergonadotropism, hypertension, hypokalemic alkalosis, and increased levels of deoxycorticosterone and progesterone (81).

In $15 \%-20 \%$ of patients with POF, an autoimmune disease is also present (82). Autoimmune POF can be seen as isolated or as part of autoimmune polyglandular diseases. More than $60 \%$ of these syndromes develop ovarian failure. Type 1 autoimmune polyglandular syndrome is rare and occurs at a young age and is autosomal recessively inherited. It causes hypoparathyroidism, mucocutaneous candidiasis, primary hypogonadism, and hypoadrenalism. Polyglandular autoimmune syndrome type 2 is more common, seen in adult patients, and has polygenic inheritance associated with HLA-DR3 and HLA-DR4. It causes adrenal insufficiency, autoimmune thyroid disease, type 1 diabetes, and gonadal failure. In patients with POF, other autoimmune diseases, such as vitiligo, myasthenia gravis, Sjögren's syndrome, systemic lupus erythematosus, celiac disease, rheumatoid arthritis, and pernicious anemia, may occur. In 11\% of patients with POF, lymphocytic oophoritis is present, and steroid cell antibodies are present in 78\% (83). Steroid cell antibodies seen in Addison's disease damage the granulosa/theca interna cells of the ovarian follicles. In $3 \%$ of patients with POF, adrenal insufficiency develops (300 times that of the general population) (84). In $90 \%$ of these patients, POF develops prior to adrenal insufficiency (85).

Chemotherapy and radiation therapy for the treatment of malignant diseases are the most common causes of POF. The effects of chemotherapy are dose- and drug-dependent (Table 1). Chemotherapy reduces the number of oocytes by damaging the DNA and disrupts the structure and function of the oocyte and granulosa cells. POF due to chemotherapeutics may be temporary; however, spontaneous recovery of ovarian function is less likely in elderly patients. In order to reduce the gonadotoxic effects of chemotherapy, simultaneous provision of GnRH analogs may be helpful (86). Radiotherapy affects the ovaries, depending on the radiation area. Radiation dose and age are other effective factors. Prepubertal ovaries are relatively more resistant to radiation (87). Approximately 2 weeks after the beginning of radiotherapy, steroid levels reduce and gonadotro- 
pins increase. Laparoscopic ovarian transposition before pelvic radiation therapy reduces the risk of POF (88). Hormone treatments have no effect on reducing the risk.

Premature ovarian failure may also develop due to mumps oophoritis. In these patients, mainly menstrual cycle disorders and infertility occur. Although there is no conclusive evidence, smoking may lead to POF, too. The idiopathic POF is a diagnosis of exclusion, and it is preferred when no other causes are ascertained; $75 \%$ to $90 \%$ of all patients are still in this group (89).

\section{Assessment of patients with POF}

Young women missing at least three consecutive menstrual cycles should be assessed. Patients diagnosed with POF should be asked in terms of both family history of mental retardation and POF. Hearing impairment may be associated with Perrault syndrome. Dry eye should be questioned in terms of autoimmune diseases. Previous operations; viral infections; treatments, such as chemotherapy and radiotherapy; and smoking should also be questioned.

In women younger than 40, at least two menopausal FSH levels ( $>40 \mathrm{IU} / \mathrm{L}$ ) will be sufficient for the diagnosis of POF. The first tests to be made in these patients to distinguish other hormonal reasons are $\mathrm{FSH}$, estradiol, prolactin, and TSH measurement. The aim of the basal LH measurement is to evaluate the presence of functional follicles. Overall, if estradiol is above $50 \mathrm{pg} /$ $\mathrm{mL}$ and $\mathrm{LH}$ level is above the level of $\mathrm{FSH}$, this is an indication that there are at least several live follicles. Nowadays, anti-ovarian antibodies are not considered to be valuable, and it is more important to investigate the anti-adrenal antibodies, as patients with POF develop adrenal insufficiency 300 times more often than the general population. Also, in terms of autoimmune thyroid diseases, it is appropriate to carry out thyroid function tests. Today, the patients with POF of unknown cause are suggested to be assessed in terms of FMR1 premutation (90). Especially in patients younger than the age of 30 or patients with primary amenorrhea, karyotype analysis must be carried out. Further tests may be carried out, depending on other clinical suspicions, such as galactosemia.

Transvaginal or pelvic ultrasound is important for the antral follicle count. Antral follicles are round or oval-shaped anechoic structures $5-10 \mathrm{~mm}$ in diameter. Ultrasound is important in the identification of the internal genitalia of primary amenorrheic patients and also, if necessary, in order to display the streak gonads. Ovarian biopsy is not necessary in patients with POF and normal karyotype.

\section{Management}

Behavioral changes, such as quitting smoking, should be accomplished primarily in order to reduce the risk of premature ovarian failure. Laparoscopic ovarian transposition before pelvic radiotherapy is likely to prevent ovarian failure. In order to prevent chemotherapy-induced and age-related follicle loss, hormonal manipulation has become widespread in recent years (91). Also, cryopreservation of ovarian tissue prior to chemotherapy is still accepted as an experimental method but is getting popular recently (92).
Exogenous hormone replacement therapy (HRT) should be recommended to patients to prevent menopausal symptoms, bone mineral density loss, and cardiovascular endothelial function deterioration. Although patients take HRT, they should be warned in terms of contraception if they do not wish to get pregnant. After diagnosis, spontaneous ovulation may occur in $25 \%$ of POF patients, and pregnancy may occur in $10 \%$, regardless of the treatment (90). It is recommended that barrier protection methods be used despite oral contraceptives if the patients do not want pregnancy. It is not yet understood how these patients can ovulate and conceive under such treatment with high doses of steroids. It is more appropriate to give exogenous estrogen and cyclic progesterone to POF patients. For this purpose, applying transdermal $17 \beta$-estradiol (initial dose $0.1 \mathrm{mg}$ ) and $100 \mathrm{mg}$ of micronized progesterone for 14 days is considered a good treatment regimen.

Unfortunately, the chance of success of ART in patients with POF is low. Even after the suppression of gonadotropin, ovulation induction, spontaneous ovulation, and pregnancy rates can not be captured (93). Although not legal in our country, in some developed countries, the chance of pregnancy is increased in these patients with oocyte donation.

\section{Ethics Committee Approval: N/A. \\ Informed Consent: $N / A$}

Peer-review: Externally peer-reviewed.

Author contributions: Concept - B.Ö.; Design - B.Ö., Y.E.S.,; Supervision - B.Ö.; Resource - B.Ö.; Materials - Y.E.S.., B.Ö.; Data Collection\&/or Processing - I.B.K, Y.E.S.., B.Ö.; Analysis\&/ or Interpretation - I.B.K., Y.E.Sु., B.Ö.; Literature Search - I.B.K., Y.E.S.; Writing - I.B.K., Y.E.S., B.Ö.; Critical Reviews - B.Ö.

Conflict of Interest: No conflict of interest was declared by the authors.

Financial Disclosure: The authors declared that this study has received no financial support.

\section{References}

1. Leridon H. Demographic effects of the introduction of steroid contraception in developed countries. Hum Reprod Update 2006; 12: 603-16. [CrossRef]

2. te Velde ER, Pearson PL. The variability of female reproductive ageing. Hum Reprod Update 2002; 8: 141-54. [CrossRef]

3. Lisabeth L, Harlow S, Qaqish B. A new statistical approach demonstrated menstrual patterns during the menopausal transition did not vary by age at menopause. J Clin Epidemiol 2004; 57: 484-96. [CrossRef]

4. Den Tonkelaar I, te Velde ER, Looman CW. Menstual cycle lenght preceding menopause in relation to age at menopause. Maturitas 1998; 29: 115-23. [CrossRef]

5. Faddy MJ, Gosden RG, Gougeon A, Richardson SJ, Nelson JF Accelerated disappearance of ovarian follicles inmidlife: Implications for forecasting menopause. Hum Reprod 1992; 7: $1342-6$.

6. Schwartz D, Mayaux MJ. Female fecundity as a function of age: Results of artificial insemination in 2193 nulliparous women with azoospermic husbands. Federation CECOS. N Engl J Med 1982; 306: 404-6. [CrossRef] 
7. van Noord-Zaadstra BM, Looman CW, Alsbach H, Habbema JD, te Velde ER, Karbaat J. Delaying childbearing: effect of age on fecundity and outcome of pregnancy. BMJ 1991; 302: 1361-5. [CrossRef]

8. Treloar AE, Boynton RE, Behn BG, BrownBW. Variation of the human menstrual cycle through reproductive life. Int J Fertil 1967; 12: 77-126.

9. Broekmans FJ, Faddy MJ, Scheffer G, te Velde ER. Antral follicle counts are related to age at natural fertility loss and age at menopause. Menopause 2004; 11: 607-14. [CrossRef]

10. Treloar AE. Menstrual cyclicity and the pre-menopause. Maturitas 1981; 3: 249-64. [CrossRef]

11. De Bruin JP, Bovenhuis H, Van Noord PAH, Pearson PL, van Arendonk JA, te Velde ER, et al. The role of genetic factors in age at natural menopause. Hum Reprod 2001; 16: 2014-8. [CrossRef]

12. van Zonneveld P, Scheffer GJ, Broekmans FJ, Blankenstein MA, de Jong FH, Looman CW, et al. Do cycle disturbances explain the agerelated decline of female fertility? Cycle characteristics of women aged over 40 years compared with a reference population of young women. Hum Reprod 2003; 18: 495-501. [CrossRef]

13. Burger HG, Hale GE, Dennerstein L, RobertsonDM. Cycle and hormone changes during perimenopause: the key role of ovarian function. Menopause 2008; 15: 603-12. [CrossRef]

14. de Koning $\mathrm{CH}$, McDonnell J, Themmen AP, de Jong FH, Homburg $\mathrm{R}$, Lambalk CB. The endocrine and follicular growth dynamics throughout the menstrual cycle in women with consistently or variably elevated early follicular phase FSH compared with controls. Hum Reprod 2008; 23: 1416-23. [CrossRef]

15. Hoekstra C, Zhao ZZ, Lambalk CB, Willemsen G, Martin NG, Boomsma DI, Montgomery GW. Dizygotic twinning. Hum Reprod Update 2008; 14: 37-47. [CrossRef]

16. Burger $\mathrm{H}$. The menopausal transition- endocrinology. J Sex Med 2008; 5: 2266-73.

17. Beemsterboer SN, Homburg R, Gorter NA, Schats R, Hompes PG, Lambalk CB. The paradox of declining fertility but increasing twinning rates with advancing maternal age. Hum Reprod 2006; 21: 1531-2. [CrossRef]

18. Mehlmann LM. Stops and starts in mammalian oocytes: Recent advances in understanding the regulation of meiotic arrest and oocyte maturation. Reproduction 2005; 130: 791-9. [CrossRef]

19. Gougeon A. Regulation of ovarian follicular development in primates: Facts and hypotheses. Endocr Rev 1996; 17: 121-55. [CrossRef]

20. Andreu-Vieyra C, Lin YN, Matzuk MM. Mining the oocyte transcriptome. Trends Endocrinol Metab 2006; 17: 136-43. [CrossRef]

21. Gilchrist RB, Lane M, Thompson JG. Oocyte-secreted factors: regulators of cumulus cell function and oocyte quality. Hum Reprod Update 2008; 14: 159-77. [CrossRef]

22. Wicks J, Treloar SA, Martin NG. Using identity-bydescent information in affected sib pairs to increase the efficiency of genetic association studies. Twin Res 2004; 7: 211-6. [CrossRef]

23. Kok HS, van Asselt KM, van der Schouw YT, Peeters PH, Wijmenga C. Genetic studies to identify genes underlying menopausal age. Hum Reprod Update 2005; 11: 483-93. [CrossRef]

24. Wang TT, Ke ZH, Song Y, Chen LT, Chen XJ, Feng C. Identification of a mutation in GDF9 as a novel cause of diminished ovarian reserve in young women. Hum Reprod 2013; 28: 2473-81. [CrossRef]

25. Skillern A, Rajkovic A. Recent developments in identifying genetic determinants of premature ovarian failure. Sex Dev 2008; 2: 228-43. [CrossRef]

26. Knauff EA, Franke L, van Es MA, van den Berg LH, van der Schouw YT, Laven JSE, et al. Genome-wide association study in premature ovarian failure patients suggests ADAMTS19 as a possible candidate gene. Hum Reprod 2009; 24: 2372-8. [CrossRef]

27. Li Q, Geng XD, Zheng W, Tang J, Xu B, Shi QH. Current understanding of ovarian aging. Life Sci 2012; 55: 655-9.
28. Welt CK, Smith PC, Taylor AE. Evidence of early ovarian aging in fragile $\mathrm{X}$ premutation carriers. J Clin Endocr Metab 2004; 89: 4569-74. [CrossRef]

29. Hsu SY, Hsueh AJW. Tissue-specific Bcl-2 protein partners in apoptosis: An ovarian paradigm. Physiol Rev 2000; 80: 593-614.

30. He CY, Kraft P, Chen C, Buring JE, Paré G, Hankinson SE, et al. Genomewide association studies identify loci associated with age at menarche and age at natural menopause. Nat Genet 2009; 41: 724-8. [CrossRef]

31. Stolk L, Zhai G, van Meurs JB, Verbiest MM, Visser JA, Estrada K, et al. Loci at chromosomes 13, 19 and 20 influence age at natural menopause. Nat Genet 2009; 41: 645-7. [CrossRef]

32. Willer CJ, Scott LJ, Bonnycastle LL, Jackson AU, Chines P, Pruim R, et al. Tag SNP selection for Finnish individuals based on the CEPH Utah HapMap database. Genet Epidemiol 2006; 30: 180-90. [CrossRef]

33. International HapMap Consortium. A haplotype map of the human genome. Nature 2005; 437: 1299-320. [CrossRef]

34. Lakhal B, Laissue P, Braham R, Elghezal H, Saâd A, Fellous M, Veitia RA. BMP15 and premature ovarian failure: causal mutations, variants, polymorphisms? Clin Endocrinol (Oxf) 2010; 72: 425-6. [CrossRef]

35. Weel AE, Uitterlinden AG, Westendorp IC, Burger H, Schuit SC, Hofman A, et al. Estrogen receptor polymorphism predicts the onset of natural and surgical menopause. J Clin Endocrinol Metab 1999; 84: 3146-50. [CrossRef]

36. Kevenaar ME, Themmen AP, Rivadeneira F, Uitterlinden AG, Laven JS, van Schoor NM, et al. A polymorphism in the AMH type II receptor gene is associated with age at menopause in interaction with parity. Hum Reprod 2007; 22: 2382-8. [CrossRef]

37. Tatone C, Carbone MC, Falone S, Aimola P, Giardinelli A, Caserta $\mathrm{D}$, et al. Age-dependent changes in the expression of superoxide dismutases and catalase are associated with ultrastructural modifications in human granulosa cells. Mol Hum Reprod 2006; 12: 655-60. [CrossRef]

38. Perez GI, Jurisicova A, Matikainen T, Moriyama T, Kim MR, Takai Y, et al. A central role for ceramide in the age-related acceleration of apoptosis in the female germline. FASEB J 2005; 19: 860-2.

39. Olovnikov AM. Telomeres, telomerase, and aging: Origin of the theory. Exp Gerontol 1996; 31: 443-8. [CrossRef]

40. Rhyu MS. Telomeres, telomerase and immortality. J Natl Cancer Inst 1995; 87: 884-94. [CrossRef]

41. Kinugawa C, Murakami T, Okamura K, Yajima A. Telomerase activity in normal ovaries and premature ovarian failure. Tohoku J Exp Med 2000; 190: 231-8. [CrossRef]

42. Betts DH, King WA. Telomerase activity and telomere detection during early bovine development. Dev Genet 1999; 25: 397-403. [CrossRef]

43. Yamada-Fukunaga T, Yamada M, Hamatani T, Chikazawa N, Ogawa $\mathrm{S}$, Akutsu $\mathrm{H}$, et al. Age-associated telomere shortening in mouse oocytes. Reprod Biol Endocrinol 2013; 11: 108-18. [CrossRef]

44. Miquel J, Economos A C, Fleming J, Johnson JE Jr. Mitochondrial role in cell aging. Exp Gerontol 1980; 15: 575-91. [CrossRef]

45. Vercesi AE, Kowaltowski AJ, Oliveira HC, Castilho RF. Mitochondrial $\mathrm{Ca} 2+$ transport, permeability transition and oxidative stress in cell death: Implications in cardiotoxicity, neurodegeneration and dyslipidemias. Front Biosci 2006; 11: 2554-64. [CrossRef]

46. Tatone C, Amicarelli F, Carbone MC, Monteleone P, Caserta D, Marci R, et al. Cellular and molecular aspects of ovarian follicle ageing. Hum Reprod Update 2008; 14: 131-42. [CrossRef]

47. Van Blerkom J. The influence of intrinsic and extrinsic factors on the developmental potential and chromosomal normality of the human oocyte. J Soc Gynecol Investig 1996; 3: 3-11.[CrossRef]

48. Carbone MC, Tatone C, Delle Monache S, Marci R, Caserta D, Colonna R, Amicarelli F. Antioxidant enzymatic defences in human follicular fluid: Characterization and age-dependent changes. Mol Hum Reprod 2003; 9: 639-43. [CrossRef] 
49. Kolesnick RN, Krönke M. Regulation of ceramide production and apoptosis. Annu Rev Physiol 1998; 60: 643-65. [CrossRef]

50. Schmidt AM, Yan SD, Yan SF, Dtern DM. The biology of the receptor for advanced glycation end products and its ligands. Biochim Biophys Acta 2000; 1498: 99-111. [CrossRef]

51. Merhi Z. Advanced glycation end products and their relevance in female reproduction. Hum Reprod 2014; 29: 135-45. [CrossRef]

52. Redmer DA, Reynolds LP. Angiogenesis in the ovary. Rev Reprod 1996; 1: 182-92. [CrossRef]

53. Huey S, Abuhamad A, Barroso G, Hsu MI, Kolm P, Mayer J, Oehninger S. Perifollicular blood flow doppler indices, but not follicular po2, pco2, or ph, predict oocyte developmental competence in in vitro fertilization. Fertil Steril 1999; 72: 707-12. [CrossRef]

54. Borini A, Maccolini A, Tallarini A, Bonu MA, Sciajno R, Flamigni C. Perifollicular vascularity and its relationship with oocyte maturity and IVF outcome. Ann N Y Acad Sci 2001; 943: 64-7. [CrossRef]

55. Broekmans FJ, de Ziegler D, Howles CM, Gougeon A, Trew G, Olivennes $\mathrm{F}$. The antral follicle count: practical recommendations for better standardization. Fertil Steril 2010; 94: 1044-51. [CrossRef]

56. Mutlu MF, Erdem A. Evaluation of ovarian reserve in infertile patients. J Turk Ger Gynecol Assoc 2012; 13: 196-203. [CrossRef]

57. Göksedef BP, Idiş N, Görgen H, Rüstemoğlu Asma Y, Api M, Çetin A. The correlation of the antral follicle count and serum anti-mullerian hormone. J Turk Ger Gynecol Assoc 2010; 11: 212-5. [CrossRef]

58. La Marca A, Broekmans FJ, Volpe A, Fauser BC, Macklon NS; ESHRE Special Interest Group for Reproductive Endocrinology-AMH Round Table. Anti- Mullerian hormone (AMH): what do we still need to know? Hum Reprod 2009; 24: 2264-75. [CrossRef]

59. Dólleman M, Faddy MJ, van Disseldorp J, van der Schouw YT, Messow CM, Leader B, et al. The relationship between anti-Müllerian hormone in women receiving fertility assessments and age at menopause in subfertile women: Evidence from large population studies. J Clin Endocrinol Metab 2013; 98: 1946-53. [CrossRef]

60. La Marca A, Sighinolfil G, Radi D, Argento C, Baraldi E, Artenisio AC, et al. Anti-Mullerian hormone (AMH) as a predictive marker in assisted reproductive technology (ART). Hum Reprod Update 2010; 16: 113-30. [CrossRef]

61. Broekmans FJ, Kwee J, Hendriks DJ, Mol BW, Lambalk CB. A systematic review of tests predicting ovarian reserve and IVF outcome. Hum Reprod Update 2006; 12: 685-718. [CrossRef]

62. Persani L, Rossetti R, Cacciatore C. Genes involved in human premature ovarian failure. J Mol Endocrinol 2010; 45: 257-79. [CrossRef]

63. Coulam CB, Adamson SC, Annegers JF. Incidence of premature ovarian failure. Obstet Gynecol 1986; 67: 604-6.

64. Anasti JN. Premature ovarian failure: An update. Fertil Steril 1998; 70: 1-15. [CrossRef]

65. van Kasteren YM, Schoemaker J. Premature ovarian failure: A systematic review on therapeutic interventions to restore ovarian function and achieve pregnancy. Hum Reprod Update 1999; 5: 483-92. [CrossRef]

66. Woad KJ, Watkins WJ, Prendergast D, Shelling AN. The genetic basis of premature ovarian failure. Aust $\mathrm{N} Z \mathrm{Z}$ J Obstet Gynaecol 2006; 46: 242-4.[CrossRef]

67. Zinn AR, Tonk VS, Chen Z, Flejter WL, Gardner HA, Guerra R, et al. Evidence for a Turner syndrome locus or loci at Xp112-p221. Am J Hum Genet 1998; 63: 1757-66. [CrossRef]

68. Holland CM. 47,XXX in an adolescent with premature ovarian failure and autoimmune disease. J Paediatr Adolesc Gynecol 2001; 14: 77-80. [CrossRef]

69. Sherman SL. Premature ovarian failure in fragile $\mathrm{X}$ syndrome. Am J Med Genet 2000; 97: 189-94.[CrossRef]

70. Sullivan AK, Marcus M, Epstein MP, Allen EG, Anido AE, Paquin JJ, et al. Association of FMR1 repeat size with ovarian dysfunction. Hum Reprod 2005; 20: 402-12. [CrossRef]

71. Hundscheid RD, Sistermans EA, Thomas CM, Braat DD, Straatman $\mathrm{H}$, Kiemeney LA, et al. Imprinting effect in premature ovarian failure confined to paternally inherited fragile X premutations. Am J
Hum Genet 2000; 66: 413-8. [CrossRef]

72. Conway GS, Hettiarachchi S, Murray A, Jacobs PA. Fragile X premutaions in familial premature ovarian failure. Lancet 1995; 346: 309-10. [CrossRef]

73. Aittomäki K, Lucena JL, Pakarinen P, Sistonen P, Tapanainen J, Gromoll J, et al. Mutation in the follicle-stimulating hormone receptor gene causes hereditary hypergonadotropic ovarian failure. Cell 1995; 82: 959-68. [CrossRef]

74. Shelling AN, Burton KA, Chand AL, van Ee CC, France JT, Farquhar $\mathrm{CM}$, et al. Inhibin: A candidate gene for premature ovarian failure. Hum Reprod 2000; 15: 2644-9. [CrossRef]

75. Shelling AN. X chromosome defects and premature ovarian failure Aust N Z J Med 2000; 30: 5-7. [CrossRef]

76. Waggoner DD, Buist NR, Donnell GN. Long-term prognosis in galactosaemia: Results of a survey of 350 cases. J Inherit Metab Di 1990; 13: 802-18.[CrossRef]

77. De Baere E, Dixon MJ, Small KW, Jabs EW, Leroy BP, Devriendt K, et al. Spectrum of FOXL2 gene mutations in blepharophimosis-ptosisepicanthus inversus (BPES) families demonstrates a genotype--phenotype correlation. Hum Mol Genet 2001; 10: 1591-600.[CrossRef]

78. Di Pasquale E, Beck-Peccoz P, Persani L. Hypergonadotropic ovarian failure associated with an inherited mutation of human bone morphogenetic protein-15 (BMP15) gene. Am J Hum Genet 2004; 75: 106-11. [CrossRef]

79. Laml T, Preyer O, Umek W, Hengstschlager M, Hanzal H. Genetic disorders in premature ovarian failure. Hum Reprod Update 2002; 8: 483-91. [CrossRef]

80. Bione S, Toniolo D. X chromosome genes and premature ovarian failure. Semin Reprod Med 2000; 18: 11-7. [CrossRef]

81. Biglieri EG, Herron MA, Brust N. 17-hydroxylation deficiency in man. J Clin Invest 1996; 45: 1946-54.[CrossRef]

82. La Barbera AR, Miller MM, Ober C, Rebar RW. Autoimmune etiology in premature ovarian failure. Am J Reprod Immunol Microbiol 1988; 16: 115-22.

83. Hoeck A, Schoemaker J, Drexhage HA. Premature ovarian failure and ovarian autoimmunity. Endocr Rev 1997; 18: 107-34. [CrossRef]

84. Bakalov VK, Vanderhoof VH, Bondy CA, Nelson LM. Adrenal antibodies detect asymptomatic autoimmune adrenal insufficiency in young women with spontaneous premature ovarian failure. Hum Reprod 2002; 17: 2096-100. [CrossRef]

85. Turkington RW, Lebovitz HE. Extra-adrenal endocrine deficiencies in Addison's disease. Am J Med 1967; 43: 499-507.[CrossRef]

86. Blumenfeld Z, Eckman A. Preservation of fertility and ovarian function and minimization of chemotherapy-induced gonadotoxicity in young women by GnRH-a. J Natl Cancer Inst Monogr 2005; 34: 40-3. [CrossRef]

87. Beerendonk CC, Braat DD. Present and future options for the preservation of fertility in female adolescents with cancer. Endocr Dev 2005; 8: 166-75. [CrossRef]

88. Morice P, Thiam-Ba R, Castaigne D, Haie-Meder C, Gerbaulet A, Pautier $\mathrm{P}$, et al. Fertility results after ovarian transposition for pelvic malignancies treated by external irradiation or brachytherapy. Hum Reprod 1998; 13: 660-3. [CrossRef]

89. Nelson LM. Clinical practice. Primary ovarian insufficieny. N Eng J Med 2009; 306: 606-14. [CrossRef]

90. American College of Obstetricians and Gynecologists Committee on Genetics. ACOG committee opinion. No. 338: Screening for fragile X syndrome. Obstet Gynecol 2006; 107: 1483-5. [CrossRef]

91. Ataya KM, Rao LV, Lawrence E, Kimmel R. Luteinizing hormonereleasing hormone agonist inhibits cyclophosphamide-induced ovarian follicular depletion in rhesus monkeys. Biol Reprod 1995; 52: 365-72. [CrossRef]

92. Şükür YE, Özmen B, Sönmezer M. Cancer and ovarian tissue cryopreservation. Turk J Med Sci 2010; 40: 159-68.

93. Rebar RW, Connolly HV. Clinical features of young women with hypergonadotropic amenorrhea. Fertil Steril 1990; 53: 804-10. 